involved in transplanting them is paid for their contribution.

Because the buyers insist on using the language of gifts, the recompense for the donor - from clinics, hospitals or brokers - is tiny. So only the poor and desperate are tempted. Profiteers increase the supply through coercion.

Protecting donors' anonymity enables buyers to turn a blind eye to the source of their flesh. And as Carney puts it: "The one-two punch of anonymity and donation means that profit-taking middlemen control the entire supply chain."

The global industry in body parts exploits the varied regulations and economic conditions in different countries. The fact that body parts have often travelled across continents also obscures their source. By the time an Indian child's papers reach an adoption agency in the United States, for example, there is often no easy way of verifying whether that child was given up voluntarily.

Banning organ commerce will not help, Carney says, because the red market would be driven further underground and "Every child, the poorest would kidney or continue to supply bag of blood it in return for risshould be ible fees. Nor will labelled fully embracing with the the market work, name of the as demand will rise person who alongside supply. provided it" Physicians will find new indications for transplants as more organs become available, and as they hold out hope for ever-smaller improvements in the lives of very sick patients. A third option, to grow synthetic body parts, is appealing but remains science fiction for now.

Carney does argue that the market should be transparent, with every child, kidney or bag of blood labelled with the name of the person who provided it. The supply pool might shrink, but the criminal middlemen would be eliminated. The richer members of society - those creating most of the demand - could also learn to accept their mortality, and to question whether, in every case, the extended life that a transplant promises is worth the human suffering it costs farther back along the chain. It's not much of a sticking plaster, but The Red Market is a reminder that there are some problems that science alone cannot solve.

Laura Spinney is a writer based in Lausanne, Switzerland. e-mail:1fspinney@gmail.com

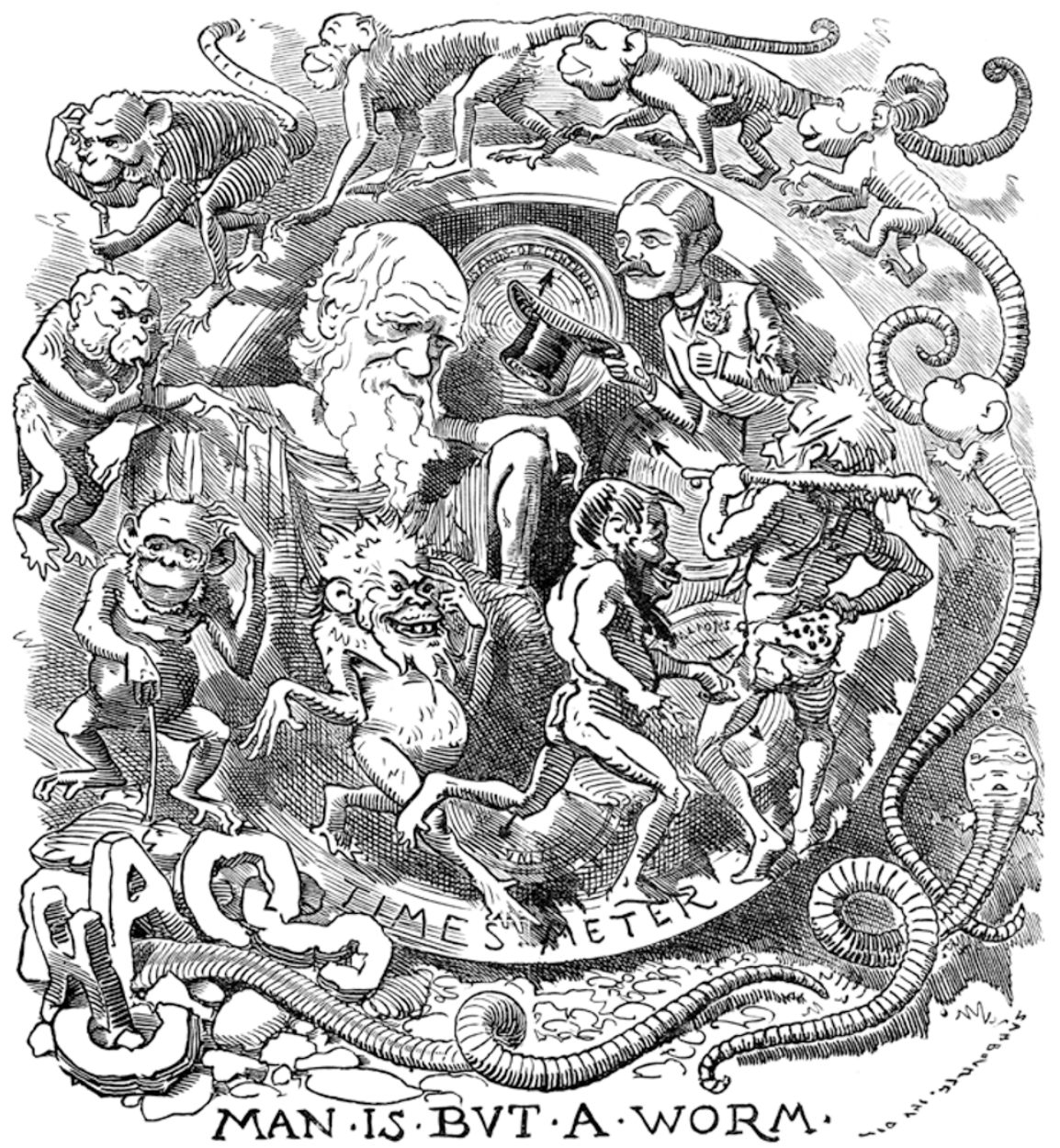

An 1881 Punch cartoon satirizing Charles Darwin's body of work that connected humans with worms. EVOLUTION

\title{
Darwin's other books
}

\section{From geology to mould, the naturalist's publications form a coherent whole, finds Eugenie Scott.}

$\mathrm{M}$ ost people are familiar with On the Origin of Species, but few are aware of Charles Darwin's decades of productive work before and after its publication. Indeed, creationists present Darwin as a one-trick pony: a rich dilettante who loafed around his country manor until he stumbled across evolution by natural selection. So I was delighted to read Steve Jones's The Darwin Archipelago (published in Britain as Darwin's Island), an entertaining and thoughtful treatment of Darwin's other books.

Darwin was a respected scientist - and a recipient of the Wollaston Medal, the Geological Society of London's highest award - well before the Origin's publication in 1859. By then, he had eight books to his name, starting with The Voyage of the Beagle in 1839 and followed by three volumes on geology and four on barnacles. Ten further books and monographs appeared after the Origin, including The Formation of Vegetable Mould, through the Action of $\underset{\varpi}{\stackrel{4}{~}}$ Worms, which was published in 1881, the year before his death at the age of 72 .

As in his earlier treatment of the Origin, titled Almost Like a Whale (published in the United States as Darwin's Ghost), Jones shows how Darwin's ideas have inspired and been augmented by subsequent research. And Jones shows his flair for a one-liner: a worm is an "animated intestine", and molecular biology is "no more than comparative anatomy plus a mountain of cash".

Jones notes that all of Darwin's work $\rightarrow$ NATURE.COM

For more, see Nature's Darwin 200 special issue: nature.com/darwin 


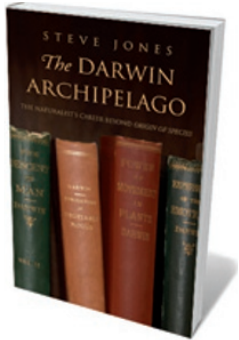

The Darwin

Archipelago:

The Naturalists's

Career Beyond

Origin of Species

STEVE JONES

Yale University Press:

2011. 248 pp. $\$ 27.50$

supports the principle that, driven by natural selection, small changes "given time, can produce gigantic ends". Anatomy, behaviour, biogeography, embryology - so many characteristics of organisms can be explained by selection on precursors that gave some advantage to their possessors. The peculiar "contrivances" of insectivorous plants to attract and capture prey, for example, can be explained only by natural selection.

Darwin's works also show what his contemporary William Whewell referred to as "consilience": the confluence of evidence from a variety of sources. As Jones puts it: “The great naturalist's lifelong labours generated an archipelago of information; a set of connected observations that together form a harmonious whole."

Time and again, Jones's book caused me to reflect on how delighted Darwin would have been to have had some titbit of evidence discovered after his death — such as the fossilized bee found with a pollen sac attached, which sheds light on the evolution of plants, or the discovery of genes for olfaction in mice. This latter finding supplements Darwin's observations of the importance of urine marking in mice for choosing a mate and avoiding inbreeding.

The last chapter is depressing but important. Introduced plant and animal species sometimes spread at the expense of natives, reducing diversity, Jones notes. Similarly, our own species has become less diverse: as our ability to manipulate the environment has grown, the variance in human death rates and birth rates has fallen, and variation within and between populations has declined because of migration and intermixing. Yet this variation is the key to adaptation by natural selection.

What does this say for the future? We know that environmental pressures will require adaptation. "One day, [Darwin's] machine will take its revenge," Jones warns. "We may well fail in the struggle for existence against ourselves, the biggest ecological challenge of all." Natural selection bats last..

Eugenie Scott is executive director of the National Center for Science Education, Oakland, California 94609, USA.

e-mail:scott@ncse.com

\section{Q\&A Christiaan Zwanikken The machinist}

Dutch artist Christiaan Zwanikken makes computer-controlled mechanical sculptures, many of which use animal skeletons he has found. As a film about Zwanikken's work and life at an isolated Portuguese convent premieres in Edinburgh, UK, he discusses human relationships with other animals and machines.

\section{Can you describe your artworks?}

I take the remains of animals and plants and bring them back to life by means of computer-controlled motors, or servos. The sculptures can interact with people and each other. There is a strong natural element and a technological part; for example, one of my sculptures has two goat skulls that bang into each other using a pneumatic system. Another is a snake eagle that dives down from a height of ten metres to meet a Duracell bunny. There is a hare skull to which I gave a new copper face. And I have five masks with little tongues that repeat lines from the 1982 film Blade Runner, in which an android asks for a longer life.

\section{How did you become interested in machines and animals?}

My grandfather was an aeroplane technician, and as a child I worked with him in his basement full of exotic parts of aeroplanes. Then my family moved to an isolated convent in rural Portugal and I explored the natural surroundings. I had dreams of machines that could fly, jump and swim. When I was at art school I had three dog skulls in my studio, and I arranged them into a mechanical Cerberus, the manyheaded dog that guards the underworld in classical mythology. People were really shocked by it.

\section{What technologies do you use?}

I use old-fashioned materials such as cogs and wheels, clockwork devices, electromagnetic coils and servos, as well as radar and ultrasonic sensors. I create an illusion, but also give away my tricks by leaving the mechanisms exposed. Although computeraided manipulation of materials is getting cheaper, I build my machines by hand. The biggest part of

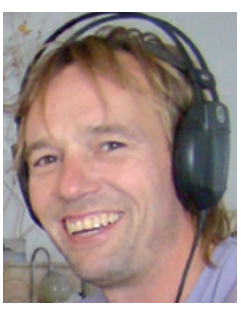

Convento DIRECTED BY JARRED ALTERMAN Edinburgh International Film Festival, 19 June. Sculptures on show 15-26 June.

Paranoia Gare Saint Sauveur, Lille, France. Until 15 August.

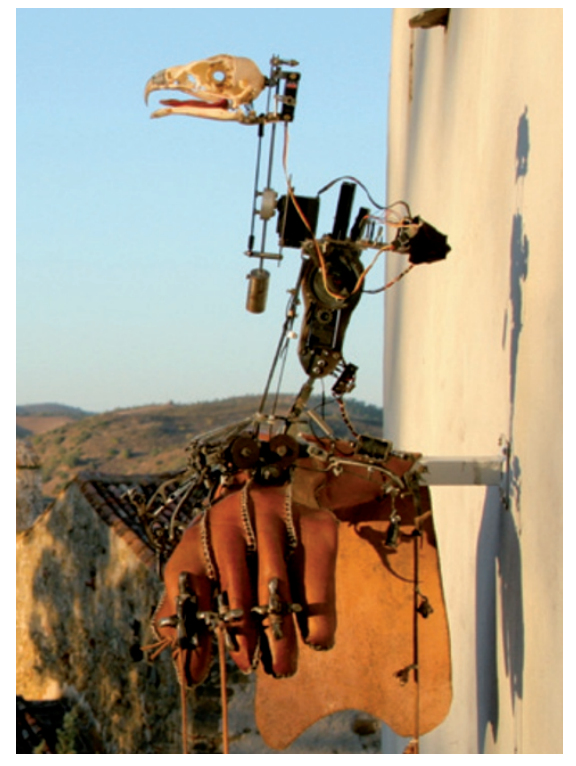

Mechatronics gives an eagle skull new life.

my work is programming them so that they seem to behave naturally.

\section{What point are you trying to make?}

I am trying to unravel humans' relationship with nature. We have rudimentary reactions to other animals, often a fight-or-flight reaction. There is a dark side to my work, perhaps a warning about the loss of species. But I also try to merge the worlds of animal and machine, so that they coexist peacefully. I try to make something that appears to be real, using technology to create a world that no one has seen before.

\section{What is your most recent piece?}

My installation Scorched Earth, on show until 15 August at an exhibition in Lille, France, is a post-apocalyptic landscape in which all flora and fauna are extinct and the remains of animals have been combined with machines to populate the world. The artificial animals are autonomous, intelligent and uncontrollable. Humans exist only as a memory. The morning it was finished, I saw the images from Japan after the tsunami. They seemed strikingly familiar. 